\title{
The Educational Impact of Experience Overseas
}

\section{Fox T, Byrne G, Byrne-Davis L.}

\begin{abstract}
Background: Healthcare professionals are increasingly seeking overseas experience as part of their training. In the UK and Ireland, spending time overseas is becoming increasingly common during the first few years of training, with 10.8 per cent of foundation year 2 (postgraduate year 2) doctors working outside the UK in 2015. Whilst we know that doctors in training are increasingly seeking overseas experience, the reasons behind this are unknown. Many travel with the intention of returning after a period of time. With medical 'gap years' becoming common, there is a need to understand the reasons behind this phenomenon and what doctors take away from their overseas experience.
\end{abstract}

Methods: We interviewed 20 British and Irish doctors in training who had spent time working in another high-income country before choosing to return home. A qualitative study was conducted to explore their experiences and what they learned from them.

Findings: Doctors in training reported choosing to travel overseas to experience living abroad, take a break from training and help them decide on their specialty choice. Participants reported a positive experience, with increased motivation, a greater sense of perspective, increased confidence, improved clinical skills and a better-informed decision on which specialty they wished to pursue. 
Discussion: Working overseas can be a positive educational experience for doctors in training. Although increasing numbers of doctors are choosing to work abroad, many wish to return to their countries of origin to complete training, and doctors should not be discouraged from undertaking additional experience overseas.

(246 words) 


\section{INTRODUCTION AND BACKGROUND}

In an era of unprecedented international mobility, doctors are increasingly moving between high-income countries (HICs) to gain experience working overseas. In $2015,5.5$ per cent $(394 / 7168)$ of doctors had obtained a post outside the UK compared with 3.8 per cent in 2014 [1]. Requests for Certificates of Current Professional Status, also known as Certificates of Good Standing, which doctors must obtain from the General Medical Council to work abroad, have risen annually since records began in 2008 (4564 requests in 2008 compared to 4926 in 2014) [2]. Elsewhere, of the doctors working in Switzerland, the proportion who were German-born increased from 12 per cent in 2000 to 30 per cent in 2010 [3].

The reasons for this trend have not been studied in depth. Whilst some doctors move abroad permanently, many are thought to return, and short-term migration is becoming increasingly common amongst highly skilled individuals in HICs [4,5]. The

migration of doctors has traditionally been seen as a negative phenomenon that causes countries of origin to lose highly skilled individuals, exerting pressure on their healthcare systems and complicating workforce planning [3]. Indeed, recent UK media reports and the 2015 UK Foundation Programme report (detailing doctors' career choices after their second postgraduate year) have raised concerns about large numbers of doctors moving overseas $[1,5,6]$.

For countries of both origin and destination, however, temporary migration can also be deemed beneficial, because it increases the volume of interactions between highly skilled individuals and thus increases potential knowledge exchange [4]. Health services are also thought to benefit from the increased breadth of experience and training opportunities that international work offers [7], while the benefits for 
the doctors themselves are well documented and include increased motivation, productivity and the dissemination of new ideas [1].

This study explores the experiences of British and Irish doctors who have spent time working in Australia and New Zealand to examine the educational value of overseas experience.

\section{METHODS}

\section{Participants}

Twenty doctors in training from the UK and Ireland who had worked in Australia and New Zealand were recruited for the study (see Table 1).

\section{INSERT TABLE 1 ABOUT HERE}

\section{Ethics}

The University of Manchester University Research Ethics Committee granted ethical approval.

\section{Procedure}

Purposive sampling was used. Initial participants were reached through advertisements on deanery (postgraduate) training websites and further participants identified via chain-referral sampling. Participants were doctors working in the UK and Ireland who had left their home countries one to three years after graduation and subsequently returned. The sample size was dictated by theoretical saturation as judged by the interviewer, i.e., when no new themes had been discussed in the previous two interviews. Semi-structured interviews were 
used, with one interviewer conducting all interviews. Interviews lasted between 30 and 60 minutes.

\section{Analysis}

The data were analysed using open and axial coding: categories (or themes) were identified and characterised and relationships between them pinpointed. A social constructivist approach was adopted [8]. An external researcher experienced in qualitative methodology assessed the theoretical verification of the findings.

\section{FINDINGS}

The findings are discussed under the main subject areas covered in the interviews:

reasons for travel, the clinical learning environment, educational benefits and reasons for return. Quotes that best represented the theme and views of the group were selected (see Table 2).

\section{INSERT TABLE 2 ABOUT HERE}

\section{Reasons for travel}

Three consistent themes emerged regarding participants' reasons for wanting to work in another HIC. The first was to aid choice of career: participants mentioned wishing to gain more experience before deciding which specialty to pursue. By working abroad, participants expected to gain time to decide about their specialty and acquire more experience in a specialty that they were considering. 
The second theme was a desire to take a break. Some wanted some respite in the form of a reduced workload; others yearned for a break from the assessments and examinations required to progress through training.

The third was a desire to experience life abroad. Participants wanted to live in a different country as a means of travelling and experiencing a new culture. They also voiced a wish to experience a different healthcare system.

\section{The clinical learning environment}

Discussions about the clinical learning environment in Australia and New Zealand compared to the UK and Ireland consistently reported that the workload was lower in the former two countries. However, two consistent themes emerged here, namely that a reduced workload does not translate into better educational experiences and an appropriate level of responsibility is needed for effective learning.

\section{Educational benefits}

Three main themes emerged when participants were asked what they had learnt from their time away. The first was an appreciation of the healthcare system in their home country. This appeared to both surprise and please the participants and may have contributed to their decision to return to their home country. The second theme was the recognition of the need to establish an adequate work-life balance. Most participants found this realisation to be positive, enabling them to establish a healthier relationship with work on returning home. The third theme suggested that time spent working overseas increased motivation for training. Participants' overseas experience had left them more mature and better able to deal with the pressures of postgraduate training. 


\section{Reasons for return}

The participants' two reasons for returning to their home country were friends and family ties back home and the perception that training was superior in their home country. They felt they were given more responsibility in their home country, which helped drive their learning and developed their decision-making skills.

\section{DISCUSSSION}

Our findings suggest that working abroad can be a positive educational experience for doctors in training.

Firstly, our participants felt that working overseas had helped them choose their specialty. To our knowledge, this has not previously been reported in the literature. Doctors in the UK are currently required to apply for specialist training 15 months after starting work [1]. Whilst this is later than in many other countries, choosing a medical specialty is recognised to be a complex decision [9] in which preferred geographical location, relationship status, number of dependents, medical school experiences and personal attributes and preferences all play a role [10]. One of the most important determinants of this decision is the individual's experience of the specialty at medical school or during training [10]. Our participants actively sought experience in specialties of interest while working overseas, and this appeared to have been beneficial in helping them decide which specialty to pursue.

Secondly, the Joint Royal Colleges of Physicians Training Board has recognised that doctors may benefit from longer, more general postgraduate training [9]. The latest Shape of Training Report (commissioned by the UK Department of Health to examine how postgraduate training meets the needs of the population) advises that for 
doctors to meet the public's changing needs, they need to be able to provide 'general care in broad specialties across a range of different settings' [9]. Experience overseas is one way of extending training and broadening one's experience.

This study was limited to exploring the reasons why doctors choose to work overseas for a short period. Interviewing long-term emigrants would yield information about why some doctors choose not to return. Our sample was also limited to trainee British and Irish doctors who had moved to Australia and New Zealand. It is unclear whether the motivation and experiences of doctors who travel between other HICs is similar, and more work is needed to explore this. The themes identified here require further exploration in larger studies with a more heterogeneous study population. To our knowledge, this is the first study that has explored the reasons behind the recent trend for increased numbers of doctors to migrate between HICs. The study focused on doctors in training as this is the cohort that has received attention from the media in the UK, but future research could usefully explore the experiences of more senior clinicians.

If media reports of a medical brain drain from the UK were proven to be true, how could the trend be reversed? The findings of this study would suggest that increased career advice, taster weeks and lengthening training may help with specialty choice, which we have shown to be a key motivation for moving abroad. However, in an increasingly globalised world, the temporary migration of doctors should not be discouraged. Scientific international mobility improves transfer of knowledge between countries [11], and medicine should be no exception. Our findings also suggest that on a personal level, working overseas increases motivation for training and encourages doctors in training to reflect on their work-life balance. Rather than 
fearing an efflux of doctors, then, HICs should celebrate the diversity of postgraduate training whilst striving to ensure that home countries offer an attractive healthcare environment in which to train and thus encouraging migrant doctors to return home at a later date. This study suggests that appropriate staffing levels and ensuring that trainees are given responsibility appropriate to their level are important contributors to an appealing learning environment. Taking care of these aspects may help ensure that postgraduate training schemes remain attractive enough to prevent a net loss of highly skilled professionals.

1504 words

\section{REFERENCES}

1 Edwards N, Kornacki M, Silversin J. Unhappy doctors: What are the causes and what can be done? BMJ 2002;324:835-38.

2 Smyth J. Australia curbs flow of disgruntled UK junior doctors. Financial Times [Internet]. 2016 Nov 1 [cited 2017 Jan 10]. Health:[about 2 p.] Available from: https://www.ft.com/content/38513e9a-a029-11e6-86d5-4e36b35c3550

3 OECD. International migration outlook 2015: Paris: OECD Publishing; 2015. Chapter 3, Changing patterns in the international migration of doctors and nurses to OECD countries; p. 105-82.

4 Ackers L. Internationalisation and equality: The contribution of short stay mobility to progression in science careers. Recherches sociologiques et anthropologiques 2010;41:83-103. 
5 Brown J. F2 career destination report 2015. Birmingham: The UK Foundation Programme Office; 2015 [cited 2017 Jan 10]. Available from: http://www.foundationprogramme.nhs.uk/index.asp?page=home/keydocs\#fpar

6 Doward J. Thousands of new doctors opt for a better life abroad. Guardian [Internet]. 2015 Aug 23 [cited 2017 Jan 10]. UK Society:[about 1 p.] Available from: https://www.theguardian.com/society/2015/aug/23/new-doctors-leave-nhs-forbetter-life-abroad

7 NHS Executive. Overseas work experience and professional development. Leeds: NHSE; 1995. Report No.: EL9569.

8 Saldana J. The coding manual for qualitative researchers. $3^{\text {rd }}$ ed. Los Angeles: Sage; 2015. 366 p.

9 Greenaway D. Shape of training: Securing the future of excellent patient care. Final report of the independent review. London: Shape of Training; 2013. 56 p.

10 Goldacre M, Laxton L, Lambert T. Medical graduates' early career choices of specialty and their eventual specialty destinations: UK prospective cohort studies. BMJ 2010;341:c3199.

11 Baruffaldi S, Landoni P. Return mobility and scientific productivity of researchers working abroad: The role of home country linkages. Res Policy 2012;41:1655-65. 
Table 1: Demographics of participants

\begin{tabular}{|c|c|c|c|c|c|}
\hline Participant & Age/Sex & $\begin{array}{l}\text { Medical School } \\
\text { Attended }\end{array}$ & $\begin{array}{l}\text { Location of } \\
\text { High-Income } \\
\text { Placement }\end{array}$ & $\begin{array}{l}\text { Time } \\
\text { Abroad } \\
\text { (Months) }\end{array}$ & $\begin{array}{l}\text { Training } \\
\text { Programme on } \\
\text { Return }\end{array}$ \\
\hline 1 & $29 / \mathrm{F}$ & Bristol & $\begin{array}{l}\text { Gold Coast, } \\
\text { Australia }\end{array}$ & 12 & $\begin{array}{l}\text { Core Medical } \\
\text { Training } \\
\text { (London) }\end{array}$ \\
\hline 2 & $29 / F$ & Edinburgh & $\begin{array}{l}\text { Brisbane, } \\
\text { Australia }\end{array}$ & 15 & $\begin{array}{l}\text { Core Surgical } \\
\text { Training } \\
\text { (London) }\end{array}$ \\
\hline 3 & $28 / F$ & Aberdeen & $\begin{array}{l}\text { Caboolture, } \\
\text { Australia }\end{array}$ & 24 & $\begin{array}{l}\text { GP Training } \\
\text { (Glasgow) }\end{array}$ \\
\hline 4 & $29 / \mathrm{M}$ & $\begin{array}{l}\text { Imperial } \\
\text { College, London }\end{array}$ & $\begin{array}{l}\text { Brisbane, } \\
\text { Australia }\end{array}$ & 11 & $\begin{array}{l}\text { Core Medical } \\
\text { Training } \\
\text { (Severn) }\end{array}$ \\
\hline 5 & $28 / F$ & Newcastle & $\begin{array}{l}\text { Blenheim, New } \\
\text { Zealand }\end{array}$ & 9 & $\begin{array}{l}\text { GP Training } \\
\text { (Edinburgh) }\end{array}$ \\
\hline 6 & $30 / \mathrm{F}$ & Bristol & $\begin{array}{l}\text { Christchurch, } \\
\text { New Zealand }\end{array}$ & 9 & $\begin{array}{l}\text { Core Medical } \\
\text { Training } \\
\text { (Birmingham) }\end{array}$ \\
\hline 7 & $28 / \mathrm{M}$ & $\begin{array}{l}\text { University } \\
\text { College, Dublin }\end{array}$ & $\begin{array}{l}\text { Brisbane, } \\
\text { Australia }\end{array}$ & 12 & $\begin{array}{l}\text { GP Training } \\
\text { (Dublin) }\end{array}$ \\
\hline 8 & $29 / \mathrm{F}$ & Bristol & $\begin{array}{l}\text { Gold Coast, } \\
\text { Australia }\end{array}$ & 24 & $\begin{array}{l}\text { GP Training } \\
\text { (Severn) }\end{array}$ \\
\hline 9 & $28 / \mathrm{F}$ & $\begin{array}{l}\text { University } \\
\text { College, Dublin }\end{array}$ & $\begin{array}{l}\text { Brisbane, } \\
\text { Australia }\end{array}$ & 12 & $\begin{array}{l}\text { Obstetrics and } \\
\text { Gynaecology } \\
\text { (Dublin) }\end{array}$ \\
\hline 10 & $30 / \mathrm{M}$ & Bristol & $\begin{array}{l}\text { Brisbane, } \\
\text { Australia }\end{array}$ & 12 & $\begin{array}{l}\text { Core Medical } \\
\text { Training } \\
\text { (Yorkshire) }\end{array}$ \\
\hline 11 & $29 / \mathrm{F}$ & Cardiff & $\begin{array}{l}\text { Alice Springs, } \\
\text { Australia }\end{array}$ & 24 & $\begin{array}{l}\text { Core Medical } \\
\text { Training } \\
\text { (London) }\end{array}$ \\
\hline 12 & $28 / \mathrm{M}$ & Nottingham & $\begin{array}{l}\text { Sunshine Coast, } \\
\text { Australia }\end{array}$ & 12 & $\begin{array}{l}\text { Core Surgical } \\
\text { Training (North } \\
\text { West) }\end{array}$ \\
\hline 13 & $29 / F$ & Manchester & $\begin{array}{l}\text { Newcastle, } \\
\text { Australia }\end{array}$ & 12 & $\begin{array}{l}\text { GP Training } \\
\text { (London) }\end{array}$ \\
\hline 14 & $29 / F$ & Southampton & $\begin{array}{l}\text { Auckland, New } \\
\text { Zealand }\end{array}$ & 24 & $\begin{array}{l}\text { GP Training } \\
\text { (North West) }\end{array}$ \\
\hline 15 & $30 / \mathrm{M}$ & Bristol & $\begin{array}{l}\text { Brisbane, } \\
\text { Australia }\end{array}$ & 11 & $\begin{array}{l}\text { Core Surgical } \\
\text { Training } \\
\text { (London) }\end{array}$ \\
\hline 16 & $30 / \mathrm{F}$ & Bristol & $\begin{array}{l}\text { Sydney, } \\
\text { Australia }\end{array}$ & 12 & $\begin{array}{l}\text { Anaesthetics } \\
\text { Training } \\
\text { (London) }\end{array}$ \\
\hline 17 & $28 / \mathrm{F}$ & Peninsula & Perth, Australia & 24 & $\begin{array}{l}\text { GP Training } \\
\text { (London) }\end{array}$ \\
\hline 18 & $29 / \mathrm{M}$ & Cambridge & $\begin{array}{l}\text { Palmerston } \\
\text { North, New } \\
\text { Zealand }\end{array}$ & 12 & $\begin{array}{l}\text { Core Medical } \\
\text { Training } \\
\text { (London) }\end{array}$ \\
\hline 19 & $28 / \mathrm{F}$ & Newcastle & $\begin{array}{l}\text { Palmerston } \\
\text { North, New } \\
\text { Zealand }\end{array}$ & 9 & $\begin{array}{l}\text { Paediatric } \\
\text { Training } \\
\text { (London) }\end{array}$ \\
\hline 20 & $29 / \mathrm{M}$ & Cardiff & $\begin{array}{l}\text { Brisbane, } \\
\text { Australia }\end{array}$ & 24 & $\begin{array}{l}\text { Core Medical } \\
\text { Training } \\
\text { (London) }\end{array}$ \\
\hline
\end{tabular}




\begin{tabular}{|c|c|c|}
\hline Discussion Topic & Theme & Supporting Quotes \\
\hline \multirow[t]{3}{*}{$\begin{array}{l}\text { Reasons for } \\
\text { travel }\end{array}$} & Aid choice of career & $\begin{array}{l}\text { I was still deciding between General Practice and Core Medical Training so it } \\
\text { just felt too soon to apply; F1 went by in a blur and I wasn't ready to commit to } \\
\text { one specialty at that stage so I just wanted to have a bit more time. (Participant } \\
\text { 5) } \\
\text { I went to Australia because I didn't know what I wanted to do, specialty-wise. } \\
\text { (Participant 12) }\end{array}$ \\
\hline & Take a break & $\begin{array}{l}\text { I expected it to be less hectic, maybe less stressful than working in the NHS. I } \\
\text { expected maybe more protected working hours, to not be working overtime, to } \\
\text { finish on time, maybe have more weekends to do things outside of work. } \\
\text { (Participant 5) } \\
\text { I was thinking of applying to paeds, which is like an eight-year run-through, } \\
\text { which is a bit daunting, so, yeah, it was like a bit of time out before that. } \\
\text { (Participant 10) }\end{array}$ \\
\hline & $\begin{array}{l}\text { Experience life } \\
\text { abroad }\end{array}$ & $\begin{array}{l}\text { I saw it as an opportunity to live overseas, which would, I thought it would be } \\
\text { fun, it would allow me to live in a different country, to experience a different } \\
\text { healthcare system. (Participant } 6 \text { ) }\end{array}$ \\
\hline \multirow[t]{2}{*}{$\begin{array}{l}\text { The clinical } \\
\text { learning } \\
\text { environment }\end{array}$} & $\begin{array}{l}\text { A reduced workload } \\
\text { does not translate } \\
\text { into better } \\
\text { educational } \\
\text { experiences }\end{array}$ & $\begin{array}{l}\text { So it was much more relaxed. There was so many staff so you rarely felt } \\
\text { pressured. (Participant 1) } \\
\text { Well what you had a lot of, it was time. You just had time to do your job, to do } \\
\text { a proper job; you could do a decent clerking, you could actually think about it } \\
\text { a little bit more. (Participant 4) }\end{array}$ \\
\hline & $\begin{array}{l}\text { An appropriate level } \\
\text { of responsibility is } \\
\text { needed for effective } \\
\text { learning }\end{array}$ & $\begin{array}{l}\text { I think perhaps I didn't learn as much as I thought I might and that's probably } \\
\text { because the jobs were, we were too well supported. We were rarely making } \\
\text { decisions, yeah, that was one of the things which was maybe a bit of a negative. } \\
\text { (Participant } 3 \text { ) } \\
\text { I think you learn less because of the lower volume of cases whereas when you } \\
\text { are doing a very busy job and seeing lots of patients I think that's a good thing } \\
\text { because you're seeing more conditions and learning about their management. } \\
\text { (Participant 18) }\end{array}$ \\
\hline \multirow[t]{4}{*}{$\begin{array}{l}\text { Educational } \\
\text { benefits }\end{array}$} & $\begin{array}{l}\text { Appreciation of the } \\
\text { healthcare system in } \\
\text { their home country }\end{array}$ & $\begin{array}{l}\text { I think it made me appreciate the NHS more; I think before I went I was quite } \\
\text { disillusioned and I thought the NHS didn't work that well after having quite a } \\
\text { negative experience of working, but having spent a year working in Australia, } \\
\text { their healthcare system seemed quite disjointed. (Participant 1) }\end{array}$ \\
\hline & $\begin{array}{l}\text { The recognition of } \\
\text { the need to establish } \\
\text { an adequate work- } \\
\text { life balance }\end{array}$ & $\begin{array}{l}\text { I think the major thing was that I want to have more of a work-life balance, and } \\
\text { this was something that was going on in New Zealand ... it taught me that } \\
\text { medicine doesn't need to be your life, that you can and should have a lot of } \\
\text { other interests. (Participant } 6 \text { ) }\end{array}$ \\
\hline & & $\begin{array}{l}\text { From a work and a personal point of view I learnt how better to sort of } \\
\text { structure my work-life balance so that I could offer more when I was at work } \\
\text { but also enjoy myself more out of work, so that was really beneficial in terms } \\
\text { of teaching me how to manage that. (Participant 7) }\end{array}$ \\
\hline & $\begin{array}{l}\text { Increased motivation } \\
\text { for training }\end{array}$ & $\begin{array}{l}\text { I think when I got back and started training again after being over there it made } \\
\text { me really motivated, I think that having a year out, doing something a bit } \\
\text { different made me more motivated when I came back. (Participant 2) }\end{array}$ \\
\hline \multirow[t]{2}{*}{$\begin{array}{l}\text { Reasons for } \\
\text { return }\end{array}$} & $\begin{array}{l}\text { Friends and family } \\
\text { ties back home }\end{array}$ & $\begin{array}{l}\text { You begin to realise that you are a very long way from a lot of people who are } \\
\text { close to you. (Participant 14). }\end{array}$ \\
\hline & $\begin{array}{l}\text { Training was } \\
\text { superior in their } \\
\text { home country }\end{array}$ & $\begin{array}{l}\text { The standard of training was just a bit different and that was probably related } \\
\text { to the volume of work that people have to do in Ireland and the level of } \\
\text { experience that people had as a result of that. (Participant } 8 \text { ) }\end{array}$ \\
\hline
\end{tabular}


Training in Australia for medical specialties is not as highly regarded as it is in the UK so I was conscious of the fact that I wanted to do my training in the UK. (Participant 1)

Table 2: Interview outcomes 